2. Ватченко О. Б.2 Андрейченко О. А. Стратегічне планування розвитку регіонів України. Економічний простір. Дніпро, 2016. № 113. C. $15-26$.

3. Вишиванюк М. В. Теоретичні передумови формування стратегії сталого розвитку регіонів. Науковий вісник Академії муніципального управління. Серія : Управління. Київ, 2012. Вип. 4. С. 284-291.

4. Гнатенко А. І. Теоретичні підходи до визначення механізму стратегічного планування у сфері державного управління регіональним розвитком. Актуальні проблеми державного управління. Харків, 2013. № 2. C. 105-113.

5. Романюк С. А. Теорія та практика стратегічного управління : монографія. Київ : НАДУ, 2019. 232 с.

6. Lykke A. Toward an Understanding of Military Strategy. Military Strategy: Theory and Application. Carlisle, PA: U.S. Army War College. 1989. P. 3-8.

7. Chandler A. Strategy and structure: Chapters in the history of the American industrial enterprise. Cambridge: MIT Press. 1962. 480 p.

8. Porter M. What is strategy? Harvard Business Review. 1996. Vol. 74. Iss. 6. P. 61-78.

\title{
DOI https://doi.org/10.30525/978-9934-26-121-3-4
}

\section{МІЖНАРОДНИЙ ДОСВІД ЗАБЕЗПЕЧЕННЯ ГЕНДЕРНОЇ РІВНОСТІ У ВИБОРЧИХ ПРОЦЕСАХ}

\author{
Редчиць О. С.
}

аспірантка Навчально-наукового інституту публічного управління та державної служби Київського наџіонального університету імені Тараса Шевченка

м. Київ, Україна

Гендерна рівність передбачає рівні права для жінок і чоловіків, дівчат i хлопців, а також їх однакову значущість, можливості, обов'язки та участь у всіх сферах суспільного й особистого життя. Так само вона означає рівний доступ жінок і чоловіків до ресурсів та розподіл цих ресурсів між ними [1, с. 5].

Процес становлення та розвитку політики гендерної рівності характеризується поступовим закріпленням рівних прав і можливостей 
жінок і чоловіків, рівності статей, недискримінацією за ознакою статі у міжнародному законодавстві та законодавствах окремих країн.

Відповідно до лічильника населення Свропи, чисельність жіночого населення переважає чоловіче на 3,6 \% [2].

Такий показник свідчить про те, що демократичний розвиток країн Європи можна забезпечити лише при рівноправній участі жінок у політичних процесах та процесах прийняття рішень.

У звіті Комітету 3 рівних можливостей жінок i чоловіків Парламентської Асамблеї Ради Європи зазначено, що відсутність рівного представництва жінок і чоловіків у розробці рішень щодо політичних та суспільно важливих питань становить загрозу для легітимності демократії та $є$ порушенням прав людини [3].

Світова спільнота та демократичні країни застосовують різні способи та інструменти за для розширення участі жінок у виборчих процесах, зокрема:

- закріплення в Конституціях принципу рівних прав та можливостей жінок і чоловіків;

- ухвалення спеціалізованих законів у сфері гендерної рівності;

- запровадження спеціалізованих інституцій та (або) уповноважених осіб з питань рівних прав та можливостей, наприклад Омбудсмена;

- включення до статутів політичних партій принципів гендерної рівності.

Політико-правовий спосіб згладжування наслідків гендерної дискримінації в усіх суспільних сферах, забезпечення представництва жінок у владних структурах, зокрема через обрання необхідного числа жінок депутатами до парламенту, а також вид позитивної дискримінації, як системи пільг, заохочень, заборон і компенсацій, спрямованих на підвищення соціального статусу жінок, визначається як гендерні квоти (gender quotas) [4, с. 212].

Експерти офісу спеціального радника 3 гендерних питань Office of the Special Advisor on Gender and Women's Opportunities Development (OSAGI) у своїй доповіді зазначають, що на представництво жінок у політичному управлінні впливають три основні чинники: партійні квоти, партійні списки та виборчі бар'єри [5].

Зібраний i проаналізований матеріал дозволяє класифікувати найрозповсюджені типи квот, що застосовуються у країнах світу. До них належать: законодавчі квоти та зарезервовані місця (закріплені в Конституціях або інших законодавчих актах країни та направленні на регулювання кількості жінок у виборчому списку), а також добровільні квоти, встановлені політичними партіями (направлені на закріплення 
рівних прав та можливостей для жінок і чоловіків, встановлюються політичними партіями без примусу з боку держави).

До важливих аспектів запровадження квотування належать також розмір квоти у відсотковому або кількісному значенні; місце розташування зарезервованої квоти (мандату) у виборчому списку; виборча система в якій застосовується квота; прозорість процесу відбору кандидатів до виборчих списків; запровадження відповідальності за порушення встановлених законодавством вимог, механізмів контролю та стимулювання у сфері гендерних зобов'язань.

Розглянемо типи квотування у співвідношенні із результатами останніх виборів до парламентів країн Свропейського Союзу, що наведено у таблиці.

Таблиця 1

Типи квотування, що застосовуються

в країнах Свропейського Союзу

\begin{tabular}{|c|c|c|c|}
\hline Країна & Тип квотування & $\begin{array}{c}\text { Результати } \\
\text { останніх } \\
\text { виборів }\end{array}$ & $\begin{array}{c}\text { Відсоток } \\
\text { жінок у } \\
\text { парламенті }\end{array}$ \\
\hline Австрія & $\begin{array}{c}\text { Законодавчі квоти на } \\
\text { національному рівні та } \\
\text { добровільні квоти, встановлені } \\
\text { політичними партіями }\end{array}$ & 73 з 183 & $39,9 \%$ \\
\hline Бельгія & $\begin{array}{c}\text { Законодавчі квоти для нижньої та } \\
\text { верхньої палат та законодавчі } \\
\text { квоти на національному рівні }\end{array}$ & 63 iз 150 & $42 \%$ \\
\hline Греція & $\begin{array}{c}\text { Законодавчі квоти для нижньої } \\
\text { палати, законодавчі квоти на } \\
\text { національному рівні та } \\
\text { добровільні квоти, встановлені } \\
\text { політичними партіями }\end{array}$ & 653300 & $21,7 \%$ \\
\hline Ірландія & $\begin{array}{c}\text { Законодавчі квоти для нижньої } \\
\text { палати }\end{array}$ & 36 iз 160 & $22,5 \%$ \\
\hline Іспанія & $\begin{array}{c}\text { Законодавчі квоти для нижньої та } \\
\text { верхньої палат, законодавчі квоти } \\
\text { на національному рівні та } \\
\text { добровільні квоти, встановлені } \\
\text { політичними партіями } \\
\end{array}$ & 153 з 350 & $43,7 \%$ \\
\hline Італія & $\begin{array}{c}\text { Законодавчі квоти для нижньої та } \\
\text { верхньої палат, законодавчі квоти } \\
\text { на національному рівні та } \\
\text { добровільні квоти, встановлені } \\
\text { політичними партіями }\end{array}$ & 2253630 & $35,7 \%$ \\
\hline Кіпр & $\begin{array}{c}\text { Законодавчі квоти на } \\
\text { національному рівні та } \\
\text { добровільні квоти, встановлені } \\
\text { політичними партіями }\end{array}$ & 12356 & $21,4 \%$ \\
\hline
\end{tabular}


International scientific conference

\begin{tabular}{|c|c|c|c|}
\hline Литва & $\begin{array}{c}\text { Законодавчі квоти на } \\
\text { національному рівні та } \\
\text { добровільні квоти, встановлені } \\
\text { політичними партіями }\end{array}$ & 39 iз 141 & $27,7 \%$ \\
\hline Люксембург & $\begin{array}{c}\text { Законодавчі квоти на } \\
\text { національному рівні та } \\
\text { добровільні квоти, встановлені } \\
\text { політичними партіями } \\
\end{array}$ & 19360 & $31,7 \%$ \\
\hline Мальта & $\begin{array}{c}\text { Законодавчі квоти на } \\
\text { національному рівні та } \\
\text { добровільні квоти, встановлені } \\
\text { політичними партіями } \\
\end{array}$ & 9 із 67 & $13,4 \%$ \\
\hline Нідерланди & $\begin{array}{c}\text { Законодавчі квоти на } \\
\text { національному рівні та } \\
\text { добровільні квоти, встановлені } \\
\text { політичними партіями } \\
\end{array}$ & 59 iз 150 & $39,3 \%$ \\
\hline Німеччина & $\begin{array}{c}\text { Законодавчі квоти на } \\
\text { національному рівні та } \\
\text { добровільні квоти, встановлені } \\
\text { політичними партіями } \\
\end{array}$ & 2233709 & $31,5 \%$ \\
\hline Польща & $\begin{array}{c}\text { Законодавчі квоти для нижньої } \\
\text { палати та законодавчі квоти на } \\
\text { національному рівні }\end{array}$ & 1303459 & $28,3 \%$ \\
\hline Португалія & $\begin{array}{c}\text { Законодавчі квоти для нижньої } \\
\text { палати та законодавчі квоти на } \\
\text { національному рівні } \\
\end{array}$ & 92 з 230 & $40 \%$ \\
\hline Румунія & $\begin{array}{c}\text { Законодавчі квоти на } \\
\text { національному рівні та } \\
\text { добровільні квоти, встановлені } \\
\text { політичними партіями }\end{array}$ & 613329 & $18,5 \%$ \\
\hline Словаччина & $\begin{array}{c}\text { Законодавчі квоти на } \\
\text { національному рівні та } \\
\text { добровільні квоти, встановлені } \\
\text { політичними партіями } \\
\end{array}$ & 34 iз 150 & $22,7 \%$ \\
\hline Словенія & $\begin{array}{c}\text { Законодавчі квоти для нижньої } \\
\text { палати, законодавчі квоти на } \\
\text { національному рівні та } \\
\text { добровільні квоти, встановлені } \\
\text { політичними партіями } \\
\end{array}$ & 24390 & $26,7 \%$ \\
\hline Угорщина & $\begin{array}{c}\text { Законодавчі квоти на } \\
\text { національному рівні та } \\
\text { добровільні квоти, встановлені } \\
\text { політичними партіями } \\
\end{array}$ & 25 з 199 & $12,6 \%$ \\
\hline Франція & $\begin{array}{c}\text { Законодавчі квоти для нижньої та } \\
\text { верхньої палат, законодавчі квоти } \\
\text { на національному рівні та } \\
\text { добровільні квоти, встановлені } \\
\text { політичними партіями } \\
\end{array}$ & 228 з 577 & $39,5 \%$ \\
\hline
\end{tabular}




\begin{tabular}{|c|c|c|c|}
\hline Хорватія & $\begin{array}{c}\text { Законодавчі квоти для нижньої палати, } \\
\text { законодавчі квоти на національному } \\
\text { рівні та добровільні квоти, встановлені } \\
\text { пелітичними партіями }\end{array}$ & 47 із 151 & $31,1 \%$ \\
\hline Чехія & $\begin{array}{c}\text { Законодавчі квоти для верхньої палати } \\
\text { та законодавчі квоти на національному } \\
\text { рівні }\end{array}$ & 463200 & $23 \%$ \\
\hline Швеція & $\begin{array}{c}\text { Законодавчі квоти на національному } \\
\text { рівні та добровільні квоти, встановлені } \\
\text { політичними партіями }\end{array}$ & 164 з 349 & $47 \%$ \\
\hline Швейцарія & $\begin{array}{c}\text { Законодавчі квоти на національному } \\
\text { рівні та добровільні квоти, встановлені } \\
\text { політичними партіями }\end{array}$ & 84 з 200 & $42 \%$ \\
\hline
\end{tabular}

Джерело: Сформовано автором на основі Бази даних гендерних квот[6].

Квотування передбачає, що жінки повинні складати певну кількість або відсоток від певної кількості місць наприклад, у законодавчому органі або у партійному списку.

Однак існують і системи квот, побудовані як нейтральні за статевою ознакою. Такий підхід може свідчити про прагнення збалансованості представників однієї статі та зазвичай характеризується тим, щоб жодна стать не займала більше 60 \% і не менше 40 \% місць.

У цьому аспекті варто взяти до уваги, що участі жінок у виборчих процесах можуть заважати різноманітні політичні, юридичні, соціальні, економічні й культурні бар'єри. До них належать: відносна обмеженість ресурсів у жінок, включаючи часові та економічні; усталені гендерні ролі; обмежений доступ до економічних активів; культурні та релігійні традиції. Квотування направлене на подолання таких бар'єрів та створення інструментів для більшої залученості жінок до виборчих процесів.

Гендерна рівність слугує однією із найважливіших передумов стабільності держави і суспільства в цілому та дозволяє ефективно функціонувати в різних умовах.

Здійснене дослідження дає можливість стверджувати, що різні виборчі системи та підходи формування списків кандидатів мають як позитивні так негативні ознаки. До позитивних відноситься: демократизація виборчого процесу шляхом запровадження прозорих процедур та рівного доступу. В свою чергу до негативних - ризик обрання кандидатів не за кваліфікацією, а за статевою ознакою.

Як свідчить досвід країн Європейського Союзу з питань гендерної рівності, важливо мати фахову, структуровану та інституціолізовану гендерну політику, що супроводжується відповідними механізмами іiі реалізації. 
Таким чином, 3 огляду на вищезазначене, можемо впевнено стверджувати, що забезпечення гендерної рівності у виборчих процесах можливе завдяки поєднанню державних механізмів, покликаних забезпечити рівність прав та можливостей жінок та чоловіків, із зміною стереотипів суспільної свідомості та поведінки.

\section{Література:}

1. Стратегія гендерної рівності Ради Європи на 2018-2023 роки. Квітень 2018 року. URL: https://rm.coe.int/prems-041318-gbr-genderequality-strategy-2023-ukr-new2/16808b35a4 (дата звернення: 25.06.2021)

2. Лічильник населення Свропи. URL: https://countrymeters.info/ru/ Europe (дата звернення: 26.06.2021)

3. Звіт Комітету 3 рівних можливостей жінок та чоловіків Парламентської асамблеї Ради Європи № 12097 від 22.01.2009. URL: https://pace.coe.int/en/files/12354 (дата звернення: 25.06.2021)

4. Гендерна рівність і розвиток: погляд у контексті Європейської стратегії України. Центр Розумкова, 2016. URL: https://razumkov.org.ua/ uploads/article/2016_Gender_rivn.pdf (дата звернення: 24.06.2021)

5. Ballington J., Matland R. Political Parties and Special Measures: Enhancing Women's Participation in Electoral Processes. United Nations Office of the Special Advisor on Gender Issues And Advancement of Women. 2004. URL: https://www.un.org/womenwatch/osagi/meetings/ 2004/EGMelectoral/EP8-BallingtonMatland.PDF (дата звернення: 25.06.2021)

6. Gender quotas database. URL: https://www.idea.int/data-tools/ data/gender-quotas/country-overview (дата звернення: 26.06.2021) 